\title{
Median Survival of Clinical Condition Improvement Factors among Patients with Type 2 Diabetes Mellitus in Semarang City, Indonesia
}

\author{
Lukman Fauzi $^{1}$, Sri Ratna Rahayu ${ }^{2}$, Anisa Wahyu Hardini ${ }^{3}$, Lindra Anggorowati ${ }^{4}$ \\ \{lukman.ikm@mail.unnes.ac.id ${ }^{1}$, sriratnarahayu@mail.unnes.ac.id ${ }^{2}$, \\ anisawahyuh@gmail.com ${ }^{3}$ \} \\ Universitas Negeri Semarang, Semarang, Indonesia ${ }^{1234}$
}

\begin{abstract}
Type 2 Diabetes Mellitus (DM) cases in Tugurejo Regional Hospital Semarang City increased up to $45,87 \%$ in 2018 . Length of stay of patient in Tugurejo Hospital was $28.74 \%$ not in accordance with INA-DRG standards. It meant the rate of clinical condition improvement inpatient was slow. The aim was to determine median survival of clinical condition improvement factors among patients with type 2 . It was historical cohort study by observing the medical records. The sample in this study was 70 . The result median survival of age variable ( $<40$ years old was 5 days), hypertension status (normal blood pressure was 6 days), obesity (normal body mass index was 6 days), blood glucose level (normal was 5 days), diet of DM (diet was 6 days), and level of dependency (self-care was 6 days).
\end{abstract}

Keywords: median survival, clinical condition, diabetes.

\section{Introduction}

Non-Communicable Disease (NCD) still becomes a public health problem, both globally, nationally and locally. About $70 \%$ of the total deaths in the world and more than half the burden of disease is Diabetes Mellitus [1]. Diabetes Mellitus (DM) caused by high blood glucose levels due to disorders of the pancreas and insulin. Based on WHO, in 2016 DM in the 7th rank causes of world death. In Indonesia, it is estimated that in 2030 there will be 21.3 million people with DM. DM in the thirdranking after stroke and Ischaemic Heart Disease (IHD), with increase from 2013 about $6.9 \%$ to $8.5 \%$ in 2017 [2].

In Central Java, DM was ranked second highest disease after hypertension is about 20.57\% [3].Semarang City was highest ranked of type 2 DM about 53.349 cases in Central Java Province in 2018 [3]. Based on Profil Kesehatan Kota Semarang 2018, the pattern of top 10 hospital diseases in the Semarang City in 2017 ranked sixth was DM by as many as 3429 cases and increased fifth ranked in 2018 with 3156 cases [4]. The prevalence of type 2 DM cases in Tugurejo Regional Hospital Semarang City in 2017 about $45.22 \%$ and increased in 2018 about $45.87 \%$. 
Research on the factors that influence the incidence of type 2 DM in Tugurejo Regional Hospital has been carried out with a variety of variables, while it is also necessary to know the survival rate of improvement in the clinical condition of type $2 \mathrm{DM}$ by applying statistical methods to determine the factors that correlated with the recovery rate. This research used analysis survival. Survival analysis is a method related to time, starting from the time origin or start point to the occurrence of a specific event (failure event/end point) [5]. Survival analysis requires data that is survival time. There are three things that must be considered in determining the survival time, namely the time origin or start point, the definition of failure event, and the clarity of the measurement scale [6].

Length of Stay (LOS) shows the correlation with the improvement of the patient's clinical condition. The longer LOS patient have, the slower the patient will experience improvement in clinical conditions. In the previous research at Tugurejo hospital in 2014 about type 2 DM disease, it was stated that the standard in INA-DRG the length of stay for DM cases was 7-20 days with the highest percentage of length of stay was 8 days and the lowest 1 day, and based on LOS patients were obtained as many as $28.74 \%$ which is not according to INA-DRG standard [7].

The survival time in this study used recovery time, started from diagnosis with type 2 diabetes and undergoing hospitalization in a hospital until it is declared to have improved clinical conditions and is allowed to go home based on the decision of the doctor specialist. Median survival is the time when $50 \%$ of subjects experience an event [8].

Previous research conducted at Wangaya Hospital in Denpasar using a survival analysis explain that in the period of 1 to 29 days from the time DM patients were hospitalized, the chances of patients surviving for less than 5 days were 0,5 and at the end of treatment, the chances of survival decreased to 0,039 , as well as variables that have a significant effect on statistics including gender, blood sugar status, and other diseases [5]. Another research on the survival analysis of DM sufferers at Makassar Bhayangkara Hospital, the factors that have a significant influence on survival time are age and blood sugar levels are bound to time, where each individual who is less than 45 years old has a risk of failure of 0,015 times less than with patients over the age of 45 years and individuals with high blood sugar levels have a risk of failure of 1,128 times greater than patients who have low and normal blood sugar levels [9]

\section{$2 \quad$ Methods}

The research was conducted in Tugurejo Regional Hospital Semarang City. This research conducted for four months since December 2019 to March 2020. The total population in this research in January-December 2018 is 206 patients. The inclusion criteria patients who are diagnosed with type 2 DM and hospitalization at Tugurejo Regional Hospital Semarang City in 2018 based on information from the medical record and covering all variables. The exclusion criteria are patients who died and discharged from the hospital without permission from the hospital. In determining the number of samples using simple random technique and the samples were 70 .

This research used was observational analytic and historic cohort design. Sources of data in this research was from medical records. The research instruments 
used in this research was observation sheet to help transfer information from medical record. The steps of data analysis in this study are as follows:

1. Recapitulate secondary data from type $2 \mathrm{DM}$ patients.

2. Identify data characteristics of type $2 \mathrm{DM}$ patients.

3. Test the proportional hazard assumption by using the Kaplan Meier curve to find out the median survival and chance of survival in DM patients.

This study uses survival analysis with looking Kaplan Meier curve to determine the dependent variable and independent variable.

The dependent variable in this study is the survival time of patients with type 2 diabetes, with the following conditions:

a. Start point (time origin), is the time when the initial patient admitted Tugurejo Hospital Semarang for hospitalization.

b. Ending event of interest is a condition when patients with type 2 DM are declared to have improved clinical conditions and are allowed to go home based on the decision of the doctor specialist.

c. The measurement scale of this study is in units of days.

The category of dependent variable divided into event and censor. Event if patient reach the goal of the patient being hospitalized and allowed to go home less than the period of time or median survival, censor if Patients who die, or lost to follow-up, or fail or are treated for more than equals the specified time period or median survival. The median survival used in this research was 8 days [10]. The independent variables in this study were sex, age, hypertension status, obesity, blood glucose level, diet of DM, neuropathy, hyperglycemia, pain, diabetic ulcers, and level of dependency. These variables are of the categorical type with two categories.

\section{Result and Discussion}

Patient characteristics are presented in several tables below.

Table 1. Patient characteristics.

\begin{tabular}{clcc}
\hline \multicolumn{2}{l}{ Patients characteristics } & $n$ & Percentage (\%) \\
\hline Sex & Male & 19 & 27.2 \\
& $-\quad$ Female & 51 & 72.8 \\
Age $\quad$ & & \\
$\quad-\quad<40$ years old & 14 & 20.0 \\
$\quad$ - $\geq 40$ years old & 56 & 80.0 \\
Occupation & & \\
$\quad$ - Civil servants & 3 & 4.2 \\
- Labor/employee & 5 & 7.1 \\
- Entrepreneur & 12 & 17.5 \\
- Retired & 17 & 24.1 \\
- Does not work & 33 & 47.1 \\
\hline
\end{tabular}

Based on the table 1, the number of female patients were 51 patiens $(72.8 \%)$ is higher than that of male patients were 19 patients (27.2\%). From 70 respondents, 
respondents aged $<40$ years old were 14 patients $(20.0 \%)$, while respondents aged $\geq 40$ years old were 56 patients $(80.0 \%)$. The distribution of 70 respondents based on occupation, the most occupation by patients not working were 33 patients $(47.1 \%)$ and the least frequency the types of occupation were civil servants were $3(4.2 \%)$.

Table 2. Clinical condition improvement factors of DM.

\begin{tabular}{|c|c|c|c|c|c|c|c|}
\hline \multirow{2}{*}{ Variable } & \multirow{2}{*}{ Category } & \multicolumn{2}{|c|}{ Censor } & \multicolumn{2}{|c|}{ Event } & \multicolumn{2}{|c|}{ Total } \\
\hline & & $n$ & $\%$ & $n$ & $\%$ & $n$ & $\%$ \\
\hline \multirow[t]{2}{*}{ Sex } & Male & 9 & 34.6 & 10 & 22.7 & 19 & 27.1 \\
\hline & Female & 17 & 65.4 & 34 & 77.3 & 51 & 72.9 \\
\hline \multirow[t]{2}{*}{ Age } & $<40$ y.o. & 0 & 0.0 & 14 & 31.8 & 14 & 20.0 \\
\hline & $\geq 40$ y.o & 26 & $\begin{array}{c}100 \\
0\end{array}$ & 30 & 68.2 & 56 & 80.0 \\
\hline \multirow[t]{2}{*}{ Hypertension status } & Normal & 6 & 23.1 & 36 & 81.8 & 42 & 60.0 \\
\hline & $\begin{array}{l}\text { Prahypertension/ } \\
\text { Hypertension }\end{array}$ & 20 & 76.9 & 8 & 18.2 & 28 & 40.0 \\
\hline \multirow[t]{2}{*}{ Obesity } & Normal & 4 & 15.4 & 29 & 65.9 & 33 & 47.1 \\
\hline & Overweight/ obes & 22 & 84.6 & 15 & 34.1 & 37 & 52.9 \\
\hline \multirow[t]{2}{*}{ Blood glucose level } & Normal $(<200)$ & 3 & 11.5 & 26 & 59.1 & 29 & 41.4 \\
\hline & Diabetes ( $\geq 200$ ) & 23 & 88.5 & 18 & 40.9 & 41 & 58.6 \\
\hline \multirow[t]{2}{*}{ Pain } & No & 23 & 88.5 & 40 & 90.9 & 63 & 90.0 \\
\hline & Yes & 3 & 11.5 & 4 & 9.1 & 7 & 10.0 \\
\hline \multirow[t]{2}{*}{ Hyperglycemia } & No & 23 & 88.5 & 43 & 97.7 & 66 & 94.3 \\
\hline & Yes & 3 & 11.5 & 1 & 2.3 & 4 & 5.7 \\
\hline \multirow[t]{2}{*}{ Diet of DM } & Yes & 6 & 23.1 & 38 & 86.4 & 44 & 62.9 \\
\hline & No & 20 & 76.9 & 6 & 13.6 & 26 & 37.1 \\
\hline \multirow[t]{2}{*}{ Neuropathy } & No & 5 & 19.2 & 8 & 18.2 & 13 & 18.6 \\
\hline & Yes & 21 & 80.8 & 36 & 81.8 & 57 & 81.4 \\
\hline \multirow[t]{2}{*}{ Diabetic ulcers } & No & 10 & 38.5 & 20 & 45.5 & 30 & 42.9 \\
\hline & Yes & 16 & 61.5 & 24 & 54.5 & 40 & 57.1 \\
\hline Level & Self Care & 7 & 26.9 & 41 & 93.2 & 48 & 68.6 \\
\hline dependency & $\begin{array}{l}\text { Intermediate Care, Partial } \\
\text { Care, and Total Care }\end{array}$ & 19 & 73.1 & 3 & 6.8 & 22 & 31.4 \\
\hline
\end{tabular}

Based on table 2, from of 70 type $2 \mathrm{DM}$ patients, female patients experienced more events $(77.3 \%)$ and censors $(65.4 \%)$ than male patients. Patients with age $\geq 40$ years olf were highest in the event $(68.2 \%)$ and censors $(100 \%)$. In hypertension status, the highest censor status was in prahypertension/ hypertension patients $(76.9 \%)$ and the highest event status was patients with normal blood pressure $(81.8 \%)$. Similarly, in obesity and blood glucose levels, the highest cases of censors were patients with overweight/obesity $(84.6 \%)$ and patients with diabetes $(88.5 \%)$, whereas cases of the highest event were patients with normal weight $(65.9 \%)$ and normal blood sugar levels $(59.1 \%)$. In the variable pain and hyperglycemia the highest cases of events and censors are patients without pain and without hyperglycemia. Patients with neuropathy and diabetic ulcers occupy the highest event and censor status. As for the diet of DM, the highest case of event was without diet (76.9\%) and the highest censor of patients on the DM diet $(86.4 \%)$. At the level of dependency variable, intermediate care, partial 
care, and total care occupy the highest censor status $(73.1 \%)$ and self care in the highest event status $(93.2 \%)$.

Median survival is the time when $50 \%$ of subjects experience an event. Median survival can be known by drawing a horizontal line from the y-axis at the point of $50 \%$ to cross the survival line. Based on the result of Kaplan Meier Curve variables that are not tangent are age, hypertension status, obesity, blood glucose level, diet of DM, and level of dependency.

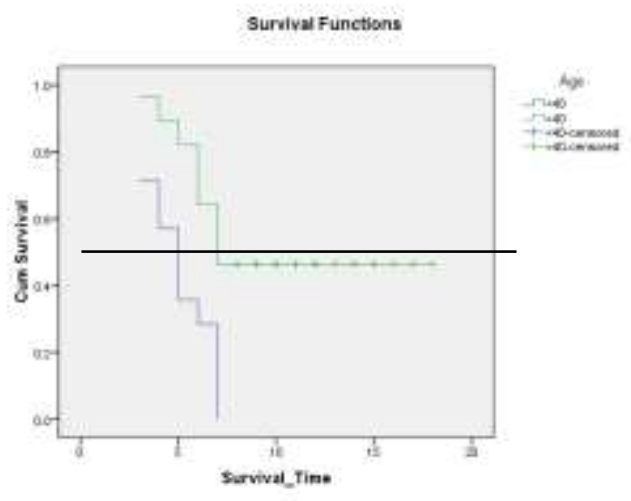

Fig. 1. Kaplan Meier curve of age.

Based on the age variable, median survival at $<40$ years old is 5 days, meaning that as many as $50 \%$ of type 2 DM patients aged $<40$ years old need 5 days to experience clinical conditions improvement. The median survival at the age of $\geq 40$ years old is 7 days, it can be concluded that $50 \%$ of DM patients aged $\geq 40$ years old need 7 days to experience clinical conditions improvement. Otherwise stated, type 2 DM patients who aged $<40$ years old need faster time to experience improvement in clinical conditions than those who have obesity aged $\geq 40$ years old.

The age variable from this study, in line with what was stated by the International Diabetes Federation, that as many as $90-95 \%$ of people with type 2 diabetes are generally over 40 years old [11]. At the age of more than 40 years, is caused by the age at which an intolerance of glucose begins to occur. The existence of the aging process causes reduced ability of $\beta$ cells in the pancreas to produce insulin [12]. With age, the ability of a person's immune system to fight viruses and destroy fungi and bacteria is reduced [13]. A high proportion of inpatients had complications, which may reflect their older age and long duration of DM [14]. DM type 2 in the elderly is accompanied by functional disability, some complications and mortality so that DM management for the elderly is very necessary [15]. 


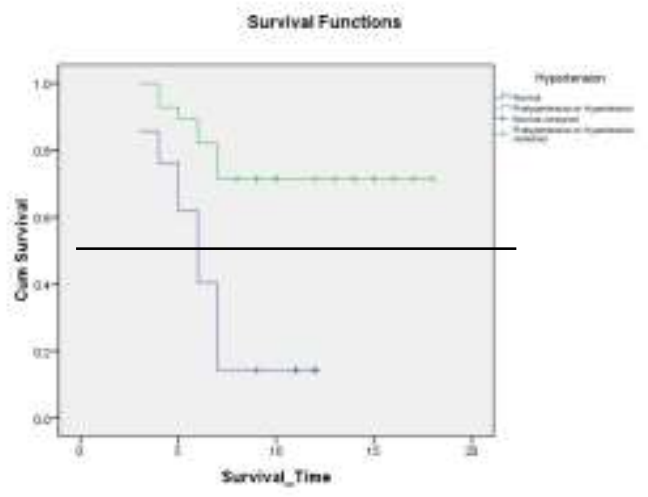

Fig. 2. Kaplan Meier curve of hypertension status.

Based on the variable hypertension status, median survival at normal blood pressure is 6 days. It can be concluded that $50 \%$ of DM patients who have normal blood pressure need 6 days to experience clinical conditions improvement. Nevertheless, this is different in prahypertension/hypertension people that shows $50 \%$ of DM patients who have need days exceeding observation time. In the other words, type $2 \mathrm{DM}$ patients who have normal blood pressure need faster time to experience improvement in clinical conditions than those who prahypertension/hypertension.

The most common type of disease suffered as a complication of type $2 \mathrm{DM}$ is hypertension. Complications such as hypertension that can occur suddenly are caused by manifestations of a poor patient's lifestyle so that the patient cannot control blood sugar levels properly [16]. In line with previous studies conducted at Ngudi Waluyo Wlingi Regional Hospital said that the survival time of improvement in the clinical condition of patients with hypertension and without hypertension is significantly different [17]. High blood pressure causes the distribution of cells to not run optimally which causes a buildup of sugar and cholesterol in the blood [18].

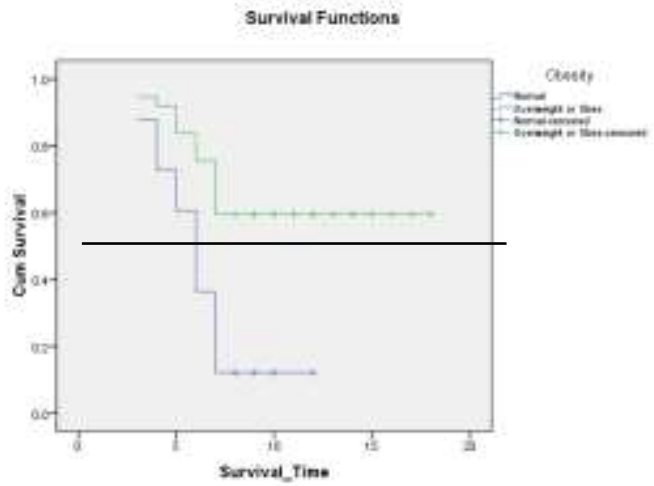

Fig. 3. Kaplan Meier curve of obesity. 
Based on the obesity variable, the median survival in patients who have a normal body mass index is 6 days. It can be concluded that $50 \%$ of DM patients who have a normal body mass index need 6 days to experience improvement in clinical conditions. However, this is different in people with overweight/obese body mass index that shows $50 \%$ of DM patients who have need days exceeding observation time. In the other words, type $2 \mathrm{DM}$ patients who have normal body mass index need faster time to experience improvement in clinical conditions than those who have overweight/obese.

The results of this study are in accordance with the theory which states that more than 8 among sufferers of type $2 \mathrm{DM}$ are those who are overweight. The more fat tissue in the body, the body tissue and muscle will be more resistant to insulin. Too much fat in the body will block the work of insulin so that glucose cannot be flowed into cells and accumulates in the blood circulation [19]. Lipoprotein abnormalities are common in overweight and obese patients with diabetes and contribute significantly to its complications [20]. In the presence of complications, the patient's clinical condition will improve more slowly.

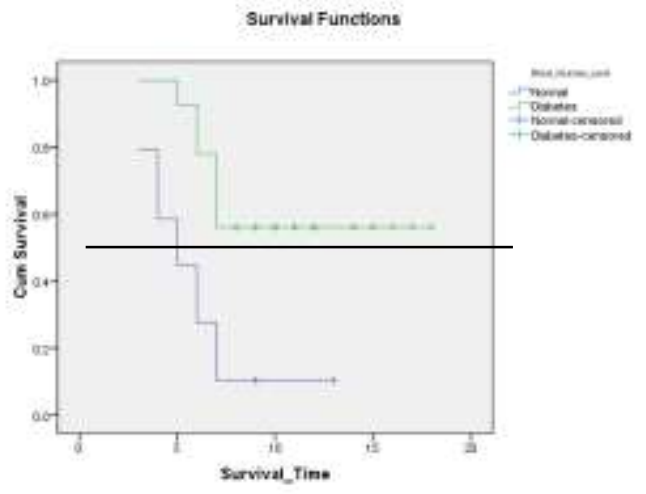

Fig. 4. Kaplan Meier curve of blood glucose level.

In the blood glucose level variable, the median survival in patients who have normal blood glucose levels or $<200 \mathrm{mg} / \mathrm{dL}$ is 5 days. The conclusion can be taken that $50 \%$ of DM patients who have normal blood glucose levels or $<200 \mathrm{mg} / \mathrm{dL}$ need 5 days to experience improvement in clinical conditions. However, this is different in people with diabetes blood glucose level $(\geq 200)$ that shows $50 \%$ of DM patients who have need days exceeding observation time. In the other words, type $2 \mathrm{DM}$ patients who have normal blood glucose level need faster time to experience improvement in clinical conditions than those who have diabetes blood glucose level.

Patients with type 2 DM who are hospitalized experience changes in diet, medications, glucose metabolism, and schedule that can adversely affect blood glucose control. Uncontrolled blood glucose levels in hospitalized patients with diabetes are associated with potential harms such as deleterious effects on wound healing, increased risk of infection, and delays in surgical procedures or discharge from the hospital [21]. The results of previous studies that respondents with blood sugar levels more than average who experienced subjective complaints of $90,9 \%$ [22]. 


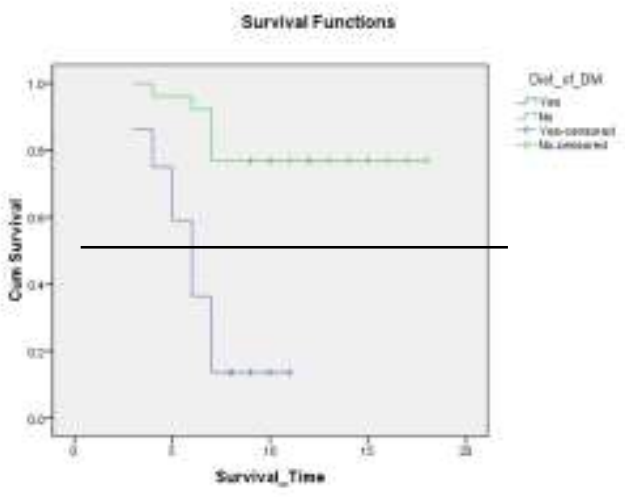

Fig. 5. Kaplan Meier curve of diet of DM.

Based on the diet of DM variables, the median survival in patients on the DM diet is 6 days. It can be concluded that $50 \%$ of DM patients who take the diet of DM need 6 days to experience clinical conditions improvement. Nevertheless, this is different in people without Diet of DM that shows $50 \%$ of DM patients who have need days exceeding observation time. Otherwise stated, type 2 DM patients who on diet of DM need faster time to experience improvement in clinical conditions than those without diet of DM.

The study that is in line with the results of this study is a survival analysis study in Wahidin Sudirohusodo Makassar Hospital, with the conclusion that patients who are not on a diet have a greater risk of failure compared to those on a diet [23]. The recommendations on dietary aspects can contribute to achieve the desired blood glucose, blood pressure, lipid profile and weight [24].

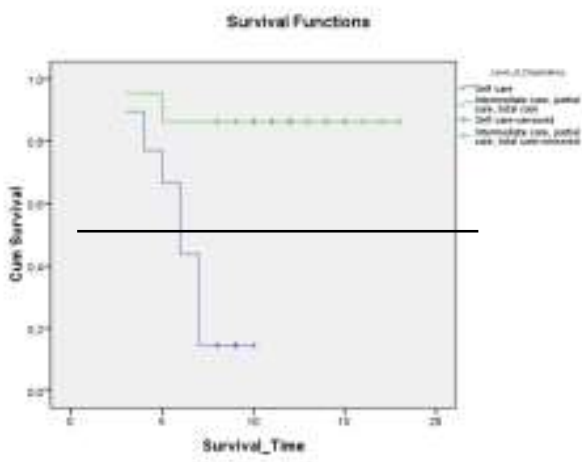

Fig. 6. Kaplan Meier curve of level of dependency.

Based on the level of dependency variable, the median survival in patients who perform self-care is 6 days. It can be concluded that $50 \%$ of DM patients who perform self-care require 6 days to experience improvement in clinical conditions. However, this is different in people with intermediate care, partial care, and total care that shows $50 \%$ of DM patients who have need days exceeding observation time. In the other 
words, type $2 \mathrm{DM}$ patients who perform self-care need faster time to experience improvement in clinical conditions than those who perform intermediate care, partial care, and total care. DM cannot be cured, it can be controlled [25]. DM patients have to learn to live with the disease. Activities that support DM management are self-care. Patients who suffer from DM for more than 5 years will realize the importance of applying self-care after the accompanying symptoms appear, so that not infrequently patients will begin to make the recommended management when signs of complications begin to appear [26].

\section{Conclusion}

The median survival or $50 \%$ of subjects experience clinical condition improvement of age variable ( $<40$ years old was 5 days, $\geq 40$ years old was 7 days), hypertension status (normal blood pressure was 6 days), obesity (normal body mass index was 6 days), blood glucose level (normal was 5 days), diet of DM (diet was 6 days), and level of dependency (self-care was 6 days).

Acknowledgments We would like to thank the Faculty of Sports Science, Universitas Negeri Semarang, Indonesia for the funding.

\section{References}

[1] WHO. World Health Statistics. 2018.

[2] Kemenkes RI. Profil Kesehatan Indonesia 2018. 2018.

[3] Dinkes Jateng. Profil Kesehatan Jawa Tengah 20182019.

[4] Dinkes Semarang. Profil Kesehatan Kota Semarang 20182019.

[5] Dewi IAPR, Suciptawati NLP, Tastrawati NKT. Aplikasi Regresi Cox Proportional Hazard pada Sintasan Pasien Diabetes Melitus. E-Jurnal Mat 2018;7:278.

[6] Kleinbaum, Klein. Survival Analysis : A Self Learning Text. New York: SpringerVerlag; 2005.

[7] Aristika D. Deskripsi Karakteristik Penderita, Lama Dirawat (LOS) dan Epidemiologi Penyakit Diabetes Mellitus Pada Pasien JKN di RSUD Tugurejo Semarang Triwulan I Tahun 20142014.

[8] Dahlan MS. Analisis Survival: Dasar-dasar Teori dan Aplikasi dengan Program SPSS. Epidemiologi Indonesia; 2012.

[9] Sanusi W. Model Regresi Cox dan Aplikasinya dalam Menganalisis Ketahanan Hidup Pasien Penderita Diabetes Mellitus di Rumah Sakit Bhayangkara Makassar. J Math Comput Stat 2018;1:62-77.

[10] Comino EJ, Harris MF, Islam MDF, Tran DT, Jalaludin B, Jorm L, et al. Impact of diabetes on hospital admission and length of stay among a general population aged 45 year or more: A record linkage study. BMC Health Serv Res 2015;15:1-13.

[11] IDF. Eighth edition 2017. IDF; 2017.

[12] Sujaya IN. Pola Konsumsi Makanan Tradisional Bali sebagai Faktor Risiko Diabetes Melitus Tipe 2 di Tabanan. J Skala Husada 2009;6:75-81.

[13] Arif A. Hubungan Faktor Komorbid, Usia dan Status Gizi dengan Lama Rawat Inap pada Pasien Hernia Inguinalis Lateralis Reponibilis yang Dioperasi Herniorepair Tanpa Mesh di RS PKU Muhammadiyah Surakarta Periode 2005 -2007. Surakarta: Universitas Muhammadiyah Surakarta; 2008. 
[14] Engler D, Gilfillan C, Soldatos G, Steele C, Ward GM. The High Burden of Inpatient Diabetes: The Melbourne Public Hospitals Diabetes Inpatient Audit. MJA 2014;201:3348.

[15] Kim B, Won JC, Lee JH, Kim H, Park JH, Ha KH, et al. Diabetes Fact Sheets in Korea, 2018: An Appraisal of Current Status. Diabetes Metab J 2019:487-94.

[16] Lubis IK. Analisis Length Of Stay (LOS) Berdasarkan Faktor Prediktor Pada Pasien DM Tipe II di RS PKU Muhammadiyah Yogyakarta. J Kesehat Vokasional 2017;2:161-6.

[17] Anggraeni LIA. Perbandingan Analisis Survival Menggunakan Regresi Weibull dan Regresi Cox Proporsional Hazard pada Penderita Diabetes Melitus Tipe II di RSUD Ngudi Waluyo Wlingi Tahun 2013. Institut Teknologi Sepuluh Nopember Surabaya 2015; 2015.

[18] Alfiyah SW. Faktor Risiko yang Berhubungan dengan Kejadian Penyakit Diabetes Melitus pada Pasien Rawat Jalan di Rumah Sakit Umum Pusat Dr.Kariadi Semarang 2011:1-62.

[19] Tandra H. Segala Sesuatu Yang Harus Anda Ketahui Tentang Diabetes. Jakarta: Gramedia Pustaka Utama; 2008.

[20] Aljabri KS, Bokhari SA, Akl A. Diabetes and Clinical Research The Relation between Overweight, Obesity and Plasma Lipids in Saudi Adults with Type 2 Diabetes. Int J Diabetes Clin Res 2015;2:2-5.

[21] Kodner C, Anderson L, Pohlgeers K. Glucose Management in Hospitalized Patients. Am Fam Physician 2017;96:650-4.

[22] Lathifah NL. Hubungan Durasi Penyakit dan Kadar Gula Darah dengan Keluhan Subyektif Penderita Diabetes Melitus. J Berk Epidemiol 2013;5:231-9.

[23] Thamrin S. Analisis Data Survival Menggunakan Metode Proportional Hazard dan Accelerated Failure Time. J Mat Stat Dan Komputasi 2008;4:97-103.

[24] Marín-peñalver JJ, Martín-timón I, Cañizo-gómez FJ. Management of Hospitalized Type 2 Diabetes Mellitus Patients. J Transl Intern Med 2016;4:155-61.

[25] Siddiqui MA, Khan MF, Carline TE. Gender Differences in Living with Diabetes Mellitus. Mat Soc Med 2013;25:140-2.

[26] Maxwel A. Diabetes Self Care Knowledge among Type 2 Diabetic Outpatients in SouthEastern Nigeria 2014. 